\title{
Era uma vez... Esta pode ser a sua história*
}

Joice Melo Vieira** $^{* *}$

\begin{abstract}
Resumo
O propósito desse artigo é analisar como a adoção é retratada em alguns livros infantis. $\mathrm{O}$ texto literário é considerado como um importante documento etnográfico capaz de esclarecer elementos culturais presentes na maneira como as pessoas vivem e pensam a adoção de crianças. Qual ideal de família permeia o imaginário social do qual esses livros são ao mesmo tempo produto e agente de difusão/reprodução? Textos e ilustrações presentes nesses livros receberam igual atenção e constatou-se que as histórias obedecem a uma mesma estrutura básica, que reveste a adoção de uma atmosfera idealizada de afetividade, aceitação e ausência de conflitos.
\end{abstract}

Palauras-chave: Adoção, Literatura Infantil, Filiação, Maternidade, Paternidade, Gênero.

\footnotetext{
* Recebido para publicação em fevereiro de 2006, aprovado em abril de 2006. Este artigo é produto da última etapa de pesquisa de mestrado sobre adoção de crianças por famílias de classe média desenvolvida sob orientação da Prof. ${ }^{a}$ Dr. ${ }^{a}$ Mariza Corrêa entre 2002 e 2004.

** Doutoranda em Demografia (Sub-área de Família, Gênero e Demografia), Núcleo de Estudos de População (NEPO/IFCH), Universidade Estadual de Campinas (UNICAMP). joicemv@uol.com.br
}

cadernos pagu (26), janeiro-junho de 2006: pp.59-85. 
Era uma vez...

Once Upon a Time...

This Should be Your Story

\begin{abstract}
The objetive of that paper is to analise how the adoption is retracted in same books for children. The literary text is considered as an important etnographic document qualified for to clear cultural elements presents in way how the people live and think the children's adoption. What family's ideal permeates social imaginary, as those books are at one time product and agent of difusion/repruduction? Texts and pictures pesents in those books received even attention. Verified that the histories have same basec struture. Adoption is reported submerged at ideal atmosphere of affection, acceptation and no conflict.
\end{abstract}

Key Words: Adoption, Literature for Children, Kinship, Maternity, Paternity, Gender. 
Joice Melo Vieira

\section{A adoção em livros infantis}

Há maior significado profundo nos contos de fadas que me contaram na infância do que na verdade que a vida ensina. (Schiller)

Nos anos 80 e, sobretudo, nos anos 90, surge uma expressiva literatura infanto-juvenil devotada à adoção. ${ }^{1}$ Ao lado de reconhecidos escritores da literatura infantil nacional, a exemplo de Ana Maria Machado $^{2}$, que inserem a adoção como tema secundário em algumas de suas obras, pais adotivos aventuram-se no universo das letras em um empreendimento que coloca a adoção, em si mesma, como questão principal de histórias infantis.

Tendo em vista que o trabalho de campo que fundamentou minha pesquisa de Mestrado $^{3}$ teve como população alvo pessoas que freqüentavam grupos de apoio à adoção ${ }^{4} e$, sabendo que o momento de revelar a adoção à criança costuma ser um dos mais angustiantes para esses pais, essas histórias infantis revestem-se de valor inestimável, porque nos reportam para o exato instante da

1 SCHREINER, Gabriela. Catálogo Bibliográfico 1000 sugestóes de leitura sobre Trabalho com Familias, Abandono, Institucionalização e Adoção. São Paulo, CECIF, 2001.

2 MACHADO, Ana Maria. A galinha que criava um ratinho. 6a. ed., São Paulo, Ática, 2002.

3 VIEIRA, Joice Melo. Os Filhos que Escolhemos: discursos e práticas da adoção em camadas médias. Dissertação de mestrado, Antropologia, Unicamp, 2004.

4 Associações e grupos de apoio à adoção encontram-se espalhados por todo o Brasil, mas a maioria se concentra na região Sudeste do país. O objetivo desses grupos é estimular a adoção e promover encontros entre pessoas que pretendem adotar ou já adoram, mas sentem necessidade de trocar suas experiências enquanto pais com outras pessoas que também são pais adotivos. Discutem medos, preconceitos, dificuldades de relacionamento com seus filhos, etc. Muitas associações são fundadas por iniciativa dos próprios pais adotivos, contudo, não raro psicólogos, assistentes sociais e advogados mantêm algum contato estreito com elas. 
Era uma vez...

revelação. Por mais que os pais adotivos possam relatar como abordaram a questão e quais foram as reações de seus filhos, não temos acesso à mais profunda intimidade das famílias.

A razão de existir do presente texto muito tem a ver com as limitações com as quais nos deparamos ao longo da pesquisa de campo. Cabe admitir que a totalidade da experiência adotiva, por mais perseguida e almejada, não foi plenamente captada por essa pesquisa, dado que foram ouvidos tão somente os pais adotivos. Um trabalho maior que comparasse e conjugasse relatos de filhos adotivos e pais adotivos e biológicos, seria capaz de ampliar significativamente a compreensão da experiência adotiva, se comparado a pesquisas isoladas que elegem uma das três partes envolvidas. Porém, para a execução de uma investigação dessa envergadura, que abarcasse as visões dos adotados, dos adotantes e dos genitores, acredito que há de se reconhecer que entrevistar adultos que são filhos adotivos seria muito diferente de entrevistar crianças adotadas. Não apenas porque, objetivamente, a sociedade ao longo do tempo encare diferentemente a adoção, a ponto de uma pessoa que foi adotada há trinta anos ter uma vivência adotiva distinta de outra adotada na última década. Mas, sobretudo, porque os adultos podem re-elaborar suas experiências ou, até mesmo, filtrá-las omitindo seus reais sentimentos.

Por outro lado, entrevistar crianças é uma tarefa que teria como primeiro desafio obter o consentimento dos pais. Ainda assim, supondo que alguns deles concordassem com a pesquisa, interrogar as crianças seria um trabalho muito delicado. $\mathrm{O}$ mais provável é que um novo instrumental metodológico precisasse ser acionado, inventado ou incorporado de outras áreas do conhecimento.

Contudo, sabendo-se que alguns pais lançam mão da literatura infantil, para introduzir a revelação da adoção aos seus filhos, apoiando-se em histórias caracterizadas pela brevidade $e$ simplicidade, como guias para contar sobre a adoção às crianças, olhar essa produção literária com algum cuidado pode ser um exercício esclarecedor. $\mathrm{Na}$ ausência de dados que me permitam 
retratar a posição das crianças e o discurso integral dos pais no instante da revelação, os livros infantis recomendados aos pais adotivos - quer nos informativos da Terra dos Homens ${ }^{5}$ ou no Catálogo Bibliográfico editado pelo Cecif ${ }^{6}$, quer diretamente indicados por um pai adotivo a outro - possibilitam que se especule sobre a forma como a adoção é tratada nas primeiras conversas com a criança. Qual colorido é dado à adoção? Que moral é reiterada nessas histórias? Qual o motivo apresentado para a adoção? Qual é a referência à família biológica, se é que ela é feita? Ao menos a título de especulação, se nos colocarmos no lugar da criança que ouve as histórias aos três ou cinco anos, qual seria nossa visão da adoção? Será que as histórias são compreensíveis e capazes de gerar identificação? Que perguntas ou inquietações essas histórias podem motivar? Elas retratam algum tipo de conflito vivido por qualquer das partes envolvidas na adoção? Até que ponto essas publicações respondem ao imaginário das crianças? Ou não são apenas feitas pelos pais adotivos, como também feitas para os pais adotivos?

Como já fizeram DaMatta ${ }^{7}$ e Darton ${ }^{8}$ que tomaram o texto literário como rico material de pesquisa para apreender

\footnotetext{
${ }^{5}$ A Terra dos Homens é uma organização não-governamental que tem trabalhado na divulgação de uma "nova cultura da adoção", entendida como aquela que não discrimina crianças mais velhas, negras ou com necessidades especiais. Suas atividades iniciaram-se em 1960 em Lausanne, Suíça, por ocasião da mobilização em torno da questão da violação dos direitos da infância em guerras. Progressivamente, seus objetivos foram sendo ampliados. $\mathrm{O}$ alvo hoje não é unicamente as crianças vitimadas por guerras, mas aquelas atingidas pela miséria, pela fome e por toda forma de violência.

${ }^{6}$ Centro de Capacitação e Incentivo à Formação de Profissionais, Voluntários e Organizações. SchreINER, G. Catálogo Bibliográfico 1000... Op. cit.

7 DAmatTA, Roberto. Poe e Lévi-Strauss no Campanário ou A obra literária como etnografia. Ensaios de Antropologia Estrutural. 2a. ed. Petrópolis, Vozes, 1977; e Mulher: Dona Flor e seus dois maridos - um romance relacional. A casa e a rua: Espaço, cidadania, mulher e morte no Brasil. São Paulo, Brasiliense, 1985.
} 
Era uma vez...

visões de mundo particulares, aproprio-me de algumas obras representativas da produção literária voltada para o público infantil como documento etnográfico. O foco central da análise será os livros escritos por pais adotivos com o propósito específico de facilitar a outros pais adotivos a revelação da adoção para seus filhos. Enquadra-se nessa categoria Conta de novo a história da noite em que eu nascI ${ }^{9}$ Bebê do coração ${ }^{10}$; $A$ história bonitinha de Maria Estrelinha ${ }^{11}$ e Mamãe: por que não nasci de sua barriga?. ${ }^{12}$

O prefácio de um dos livros aqui analisados oferece uma pista importante para explicar porque os pais adotivos sentiram necessidade de eles próprios criar uma literatura infantil específica sobre adoção:

Fevereiro de 1987. Eu, mãe de três filhos biológicos, recebo a notícia de que um bebê havia me escolhido para ser sua mãe. A sua vinda para nossa família, foi motivo de grande alegria para todos nós. Mas, apesar de toda essa felicidade, desde o início, eu sentia uma grande preocupação: "Como dizer ao meu filho que ele não havia nascido do meu ventre, sem chocá-lo?". Quando ele era ainda bebê, eu lhe dizia que ele era "o meu filhinho do coração" mas ele me pediria maiores explicações quando crescesse! Conversei com mães adotivas, li vários livros, tentei colher informações, mas nada me satisfazia. Com meu filho teria de ser diferente. Em 1990, quando ele já estava com três anos, me fez a tão temida pergunta: "MAMÃE, POR QUE

8 DARNTON, Robert. O Grande Massacre de Gatos. E outros episódios da história cultural francesa. Rio de Janeiro, Graal, 1986.

9 CuRTIS, Jamie Lee. Conta de novo a história da noite em que eu nasci. Rio de Janeiro, Salamandra, 1998. [Ilustrações: Laura Conell; tradução: Clô Franklin.]

${ }^{10}$ Laufer, Thelma Kracochansky. Bebê do Coração. São Paulo: Callis, 2002. [Ilustrações: André Neves.]

${ }^{11}$ CARVAlho, Márcia Maria Silva Lopes de. A historinha bonitinha de Maria Estrelinha. São Paulo, Edicon, 1997.

12 Domingos, Maria Salete Rodrigues. Mamãe: por que não nasci de sua barriga? Florianópolis, IOESC/Fundação Vida, 1993. 
Joice Melo Vieira

NÃO NASCI DE SUA BARRIGA?". Foi nesse exato momento que surgiu a minha história, ditada, com certeza pelo meu "Anjo da Guarda", compadecido de minha angústia e sensibilizado pelo meu imenso amor. Naquele dia, meu filho ficou sabendo que não havia nascido "De mim" mas "Para mim". A partir daí, os contos de fadas passaram para segundo plano, pois agora ele sabia de uma história na qual "ele" era o personagem principal. ${ }^{13}$

O temor dessa mãe de que o filho ficasse "chocado" ao saber da adoção merece comentário. Por que ele ficaria chocado? Poder-se-ia argumentar que a maioria das pessoas é criada por seus genitores e que uma criança, ao se descobrir adotada, poderia se sentir diferente das outras. Embora pertinente, essa explicação pode não ser suficiente. A própria atitude da criança indagando a mãe sobre o porquê não nascera de sua barriga, demonstra que ela estava apta a ler as entrelinhas e compreender que algo mais havia por trás da expressão metafórica "filhinho do coração". Curioso como as crianças têm o poder de surpreender... Essa criança percebia que havia sido gerada por outra pessoa. "Choque" seria não se obtivesse a confirmação dos pais, mas sim se eles negassem a adoção, e mais tarde a criança encontrasse provas incontestes de que havia sido enganada. Se um filho adotivo algum dia ficou "chocado" por conhecer essa passagem de sua história, é provável que isso se deva menos à adoção enquanto fato biográfico do que à forma como teve acesso a essa informação.

A citação acima evidencia duas características marcantes dos livros infantis escritos por pais adotivos: eles têm uma intencionalidade específica e um valor pragmático. Os livros são redigidos com intenção de facilitar a tarefa de contar a verdade à criança e, no entanto, cumprem também a função de aliviar as preocupações dos pais e mães sobre qual a melhor maneira de

\footnotetext{
${ }^{13}$ ID. IB., p.5.
} 
Era uma vez...

fazer isso. Estamos diante de um ponto importante que perpassa qualquer literatura. Afinal, quem escreve e para quem escreve?

Ao refletir sobre a produção literária dirigida às crianças, Perrotti afirma:

Em primeiro lugar, o fato de essa produção ser feita por adultos para crianças impõe-lhes certas direções as quais não se pode escapar. Por exemplo, não se pode negar que essa produção expressa uma visão de mundo filtrada sempre pelos interesses dos adultos produtores. $\mathrm{Na}$ realidade, a produção cultural preparada para a criança mostra-lhe não aquilo que ela, criança, seleciona, mas no máximo o que o aparelho produtor julga ser do interesse dela. Em tais condições, o olhar da criança sobre o mundo acha-se desviado, dirigido para objetos tidos pelos adultos produtores como merecedores de suas atenções. ${ }^{14}$

De fato, não só a literatura infantil ou a literatura em geral, como toda e qualquer produção cultural, seleciona, filtra a informação, no complexo jogo do dito e do não dito, de construção de evidências e ocultações. Assim, educa-se o olhar, formata-se as mentes, domestica-se (ou quiçá, adestra-se) os sentimentos. No caso do público infantil, essa operação adquire maior intensidade e importância, porque a criança está formando seu quadro referencial, sua matriz identitária, ou seja, está aberta à busca dos sentidos primeiros e a absorver os valores sociais primários que assumirá como seus.

À luz dessas colocações, vejamos o quê os textos $e$ ilustrações desses livros infantis que trazem a adoção como temática principal têm a nos dizer. Se lembrarmos que as crianças, ao tomarem o primeiro contato com essa literatura, encontram-se em idade pré-escolar, portanto, não estão alfabetizadas, a narrativa visual e a mensagem contida nela podem sobrepujar o

${ }^{14}$ Perrotti, Edmir. Confinamento cultural, infância e leitura. São Paulo, Summus, 1990, p.96. 
Joice Melo Vieira

próprio texto. Por isso, as ilustrações receberam a mesma atenção dedicada ao texto escrito.

\section{A adoção em palavras e imagens}

Como escolhi aleatoriamente os quatro livros aqui analisados, dentre a lista de títulos infantis do catálogo editado pelo Cecif, não posso afirmar, taxativamente, que o conteúdo que eles expressam seja idêntico ao de todas as publicações do gênero. Contudo, atendo-nos aos textos aqui considerados, percebe-se que eles obedecem a uma mesma estrutura.

O modelo familiar ideal em evidência é, invariavelmente, a família nuclear formada por um casal heterossexual e seus filhos. Apenas uma das quatro histórias mostrou-se sensível ao modelo familiar monoparental em uma curta, mas significativa passagem: "Quem quiser ir à Terra, quem quiser nascer, pode escolher seus pais. Aos poucos, cada um de vocês foi escolhendo as pessoas, ou a pessoa, com as quais queriam morar neste planeta azul" (Mamãe: por que não nasci de sua barriga?).

É possível notar ainda que em ao menos duas das histórias, Bebê do coração e Conta de novo a história da noite em que eu nasci, é clara a referência a recursos que evidenciam a pertença dos protagonistas às camadas médias, como observa-se nas passagens:

Compraram muitas roupinhas, muitos brinquedos, mamadeiras e chupetas. (...) Conta de novo que vocês foram me buscar de avião levando uma sacola de fraldas e mamadeiras, e que no avião só tinha amendoim pra comer $e$ nem um filmezinho pra ver.

O que deixa subentendido que se fala e, também, que se busca identificação com um público oriundo das camadas médias.

A relação conjugal aparece caracterizada pelo amor, como retrata a narrativa "vocês estavam dormindo encaixadinhos feito duas colheres" (Conta de novo a história da noite em que eu 
Era uma vez...

nasci) ou as declarações "era uma vez um casal muito apaixonado" (Bebê do coração) e "amavam-se muito" ( $A$ historinha bonitinha de Maria Estrelinha). Mas, "apesar" desse grande amor faltava alguma coisa. Eles desejavam um bebê. Do encadeamento de idéias nessas histórias infantis emerge a mensagem de que somente o amor conjugal não satisfaz as pessoas depois de certo tempo. Ele precisa ser coroado pela constituição de uma família com filhos. A filiação aparece como complementar à relação conjugal, pois sem ela não há propriamente uma família. Uma comprovação disso é o comentário registrado na contracapa de um dos livros: "Conta de novo a história da noite em que eu nasci (...) fala não só sobre o nascimento de uma criança, mas de como nasce uma família”. Ou seja, antes da constituição de prole, é como se o casal, sozinho, não pudesse ser considerado exatamente uma família.

Nessas narrativas construídas para crianças surge também a explicitação de imperativos sociais que pressionavam os casais a desejarem ter um filho:

parecia que todo mundo tinha um. [Razões sentimentais também são salientadas] (...) muitas pessoas (...) sentiam a falta de crianças que viessem alegrar a casa em que moravam. (Mamãe: por que não nasci de sua barriga?)

Nas quatro histórias o motivo que leva os casais a adotarem é exclusivamente a impossibilidade de gerar uma criança. Em dois casos a infertilidade é creditada abertamente às mulheres: "Conta de novo que você não podia ter um neném na sua barriga e por isso eu saí da barriga de uma outra moça" (Conta de novo a história da noite em que eu nasci) e "Há mulheres que podem ter filhos na barriga, mas têm outras que não podem" (Mamãe: por que não nasci de sua barriga?). Todavia, em nenhuma das histórias há alusão à infertilidade masculina da forma como ocorre em relação à infertilidade feminina. 
Embora o pai esteja presente em todos os quatro livros infantis, é também bastante revelador constatar que em três deles a figura materna tem certo predomínio sobre a paterna. A mãe é retratada como estando mais envolvida nos preparativos que concernem ao projeto adotivo do que o pai. Ainda que Sra. Lua faça constante referência a João, é Dona Estrela que precisa ser avisada que sua estrelinha está na barriga de outra estrela e é também ela quem primeiro reconhece Maria Estrelinha. Em Conta de novo a história da noite em que eu nasci, a narradora, a garotinha, dirigi-se à sua mãe a maior parte do tempo. Apenas em uma única situação ela se dirige exclusivamente ao pai:

Pai, conta de novo a primeira noite em que você cuidou de mim e ficou contando que o beisebol é um jogo que os americanos adoram. [E no final, pede a ambos] Contem de novo a história de nossa família. Mãe, pai contem de novo a história da noite em que eu nasci.

Em Mamãe: porque não nasci de sua barriga?, a narradora da história é a própria mãe dirigindo-se ao filho.

Disso pode-se inferir que subsiste, nesses livros, a representação da maternidade como central para as mulheres $e$ que a responsabilidade pela reprodução biológica é majoritariamente feminina. Uma vez inviabilizada a constituição de prole via reprodução biológica, o recurso alternativo, a adoção, é acionado. Assim, em conformidade com a noção de que a maternidade é central para as mulheres, essas histórias infantis parecem sugerir que elas se mostram mais mobilizadas pela adoção. Nesse aspecto, Bebê do coração constitui uma exceção porque do começo ao fim do texto faz-se referência aos pais no plural, e em nenhum momento evoca-se isoladamente a mãe ou o pai. Esse cuidado está presente inclusive nas ilustrações do livro. Quando o casal vai "buscar o tão sonhado bebê", a mãe antecipase ao pai, vai à frente, de braços abertos e estendidos (figura 1). Mas, em ilustração subseqüente, é o pai quem primeiro recebe o 
Era uma vez...

filho nos braços, deixando implícito um idealizado equilíbrio (figura 2).

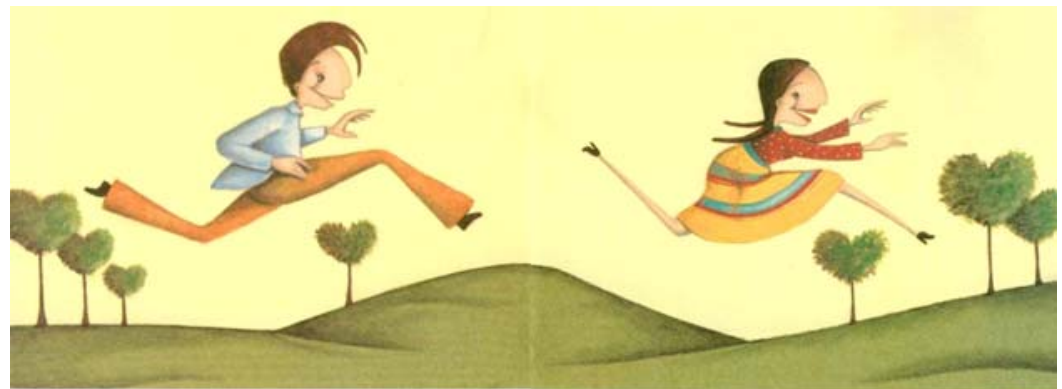

Figura 1 - Bebê do Coração, pp.12-13.

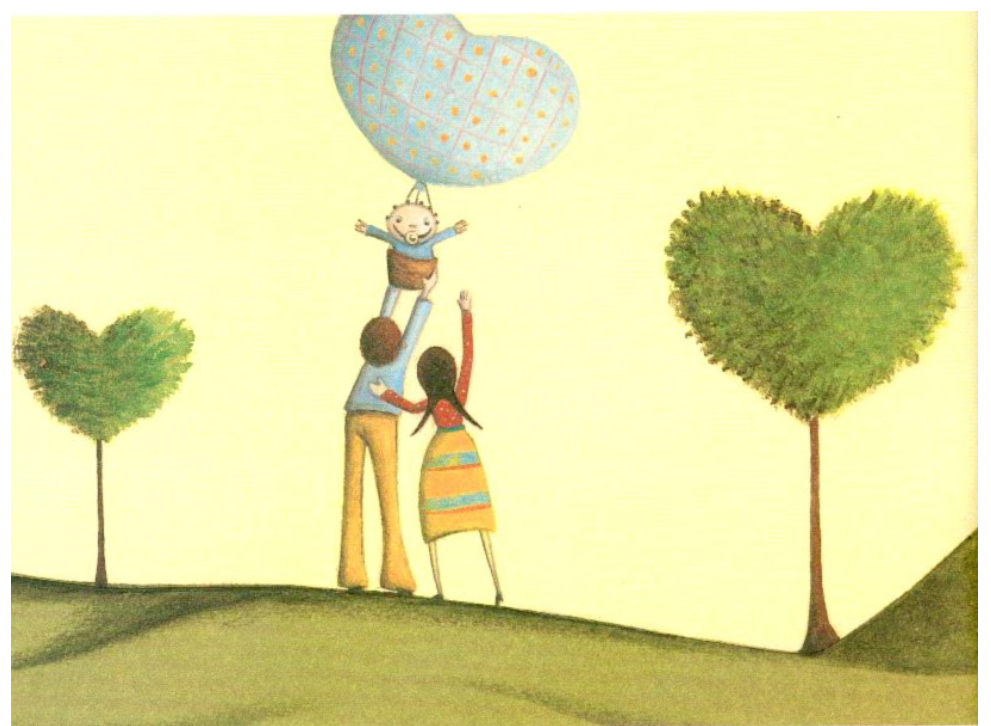

Figura 2 - Bebê do Coração, p.18. 
Joice Melo Vieira

Quando comparado aos outros três livros infantis, Bebê do Coração também se destaca por ser o único que se detém no trabalho de apontar uma variedade de prováveis razões que levaram os pais biológicos a disponibilizar o filho para adoção:

Talvez os pais biológicos fossem muito jovens, talvez eles tenham morrido. Talvez não fosse o momento certo... Talvez eles não tivessem condições para cuidar do bebê. O fato é que eles acharam que para o bebê seria o melhor.

Em Conta de novo a história da noite em que eu nasci a "moça" que emprestou a barriga "não podia cuidar de nenhuma criança". Nos demais, vigora o silêncio sobre os motivos dos pais biológicos. De qualquer maneira, a mãe biológica é tratada de forma, praticamente, metonímica. Ela é a mulher que emprestou o ventre. Não se ousa chamá-la de mãe, de acordo com o que se percebe nos trechos abaixo indicados. Isso ajuda a reiterar para a criança que mãe é uma só, aquela que a cria:

Escolher outra mãe? NUNCA!!! (...) Essas crianças que haviam escolhido mamães com problemas, deveriam vir para a Terra, na barriga de outra mulher. Mas, logo que nascessem, seriam entregues às mamães, que foram escolhidas lá no céu. (Mamãe: por que não nasci de sua barriga?)

Um dia, Dona Lua se encontra com o Sr. Sol e ele lhe diz que uma estrela cadente contou-lhe que a estrelinha de Dona Estrela estava na barriga de outra estrela, em uma constelação bem longe dali. ( $A$ historinha bonitinha de Maria Estrelinha)

(...) eu saí da barriga de uma outra moça que não podia cuidar de nenhuma criança. E eu vim para ser sua filhinha e vocês serem meus pais. (Conta de novo a história da noite em que eu nasci). 
Era uma vez...

Observando-se as gravuras desses livros infantis, nota-se a tendência de os pais biológicos não aparecerem nas ilustrações. Em dois casos o hospital é o cenário do encontro entre pais adotivos e bebê (figuras 3 e 4). Os desenhos trazem as crianças sozinhas (como na figura 4) ou nos braços da funcionária do hospital (figura 3), o que sugere o abandono físico da criança seja no hospital, ou em qualquer outro lugar, e sua desvinculação de qualquer entorno social onde tenha nascido.

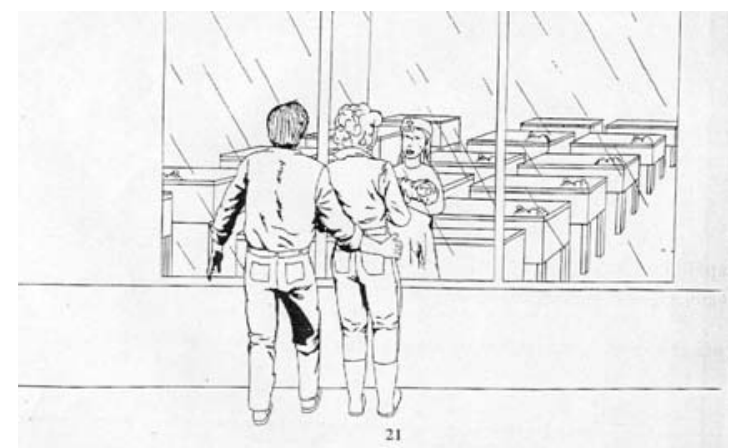

Figura 3 - Mamãe: por que não nasci de sua barriga?, p.21.

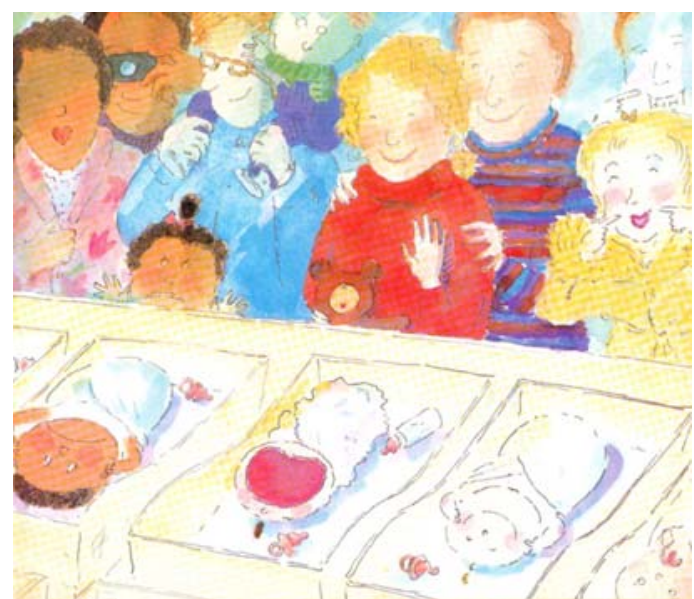

Figura 4 - Conta de novo a história da noite em que eu nasci, s/p. 
A atitude de se furtar ou evitar conferir uma imagem aos pais biológicos nos livros infantis encontra paralelo com a prática de omitir o entorno social das crianças colocadas para a adoção. Yngvesson ${ }^{15}$ chama a atenção para esse detalhe significativo ao afirmar que é praxe na adoção de crianças coreanas por suecos, que se envie fotos de crianças para os candidatos a pais, nas quais a pessoa que tem a criança nos braços é, intencionalmente, "cortada", produzindo em quem olha a imagem a idéia de abandono e de separação da criança de seu contexto social de origem. Essa mensagem também está implícita na figura 5.

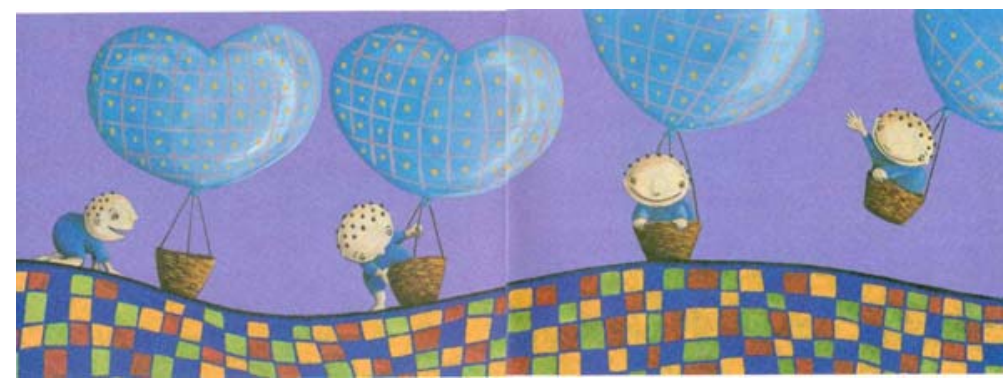

Figura 5 - Bebê do Coração, pp.16-17.

Ainda que em Conta de novo a história da noite em que eu nasci o diagrama que traça a árvore genealógica da personagem principal inclua seus genitores $e$ até lhes dê rostos, eles não são apontados como pais. São tão somente "moça que me fez" $e$ "moço que me fez". Há apenas um pai e uma mãe (figura 6). Papai e Mamãe são nomeações usadas exclusivamente para designar os pais adotivos. Atente-se ainda para o tamanho das letras. Papai e Mamãe aparecem nitidamente em destaque.

\footnotetext{
${ }^{15}$ YNGVESSON, Bárbara. Um Niño de Cualquier Color: race and nation in intercountry adoption. In: JENSEN, J. and SANTOS, B. S. Globalizing Institutions: Case Studies in Regulation and Innovation. Aldershot, Ashgate, 2000.
} 


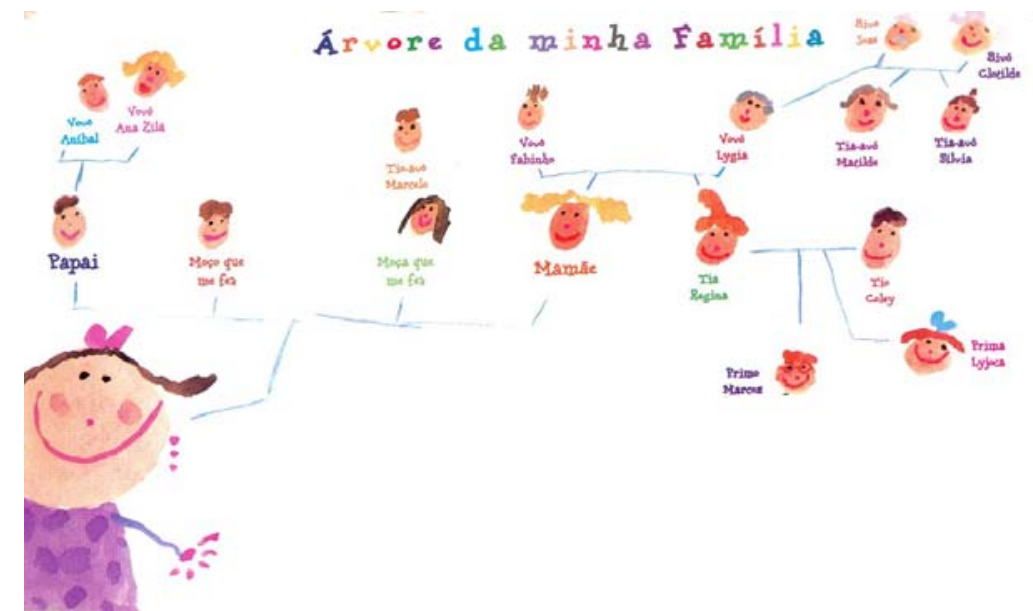

Figura 6 - Conta de novo a história da noite em que eu nasci, s/p.

O modo como a criança é descrita nesses livros infantis converge com uma concepção "sentimentalizada da infância". Zelizer ${ }^{16}$ afirma que desde o século XIX, na Europa e na América do Norte, com o processo de domesticação da família e da maternidade, que acompanhou a difusão do trabalho assalariado e da economia capitalista, as crianças foram "sacralizadas". Isto é, embora as crianças houvessem tido sua mão-de-obra explorada na primeira fase do desenvolvimento industrial, paulatinamente, cresceu o apelo da idéia da infância como um período especial, que requer cuidados, $e$ que as crianças devem ser mantidas afastas de qualquer ligação com o dinheiro. Concomitantemente, em sintonia com o processo de nuclearização da família, as crianças tornam-se preciosas e objeto de investimento sentimental.

${ }^{16}$ ZELIZER, Viviana. Repenser le marché: la construction social du 'marché aux bébés' aux Etats-Unis. Actes de la Recherche en Sciences Sociales, n 94, sept. 1992, pp.3-26. 
Yngvesson ${ }^{17}$, analisando casos de adoção internacional em que suecos adotaram crianças indianas, colombianas e sulcoreanas, mostra como a visão da infância como pura, sagrada $e$ objeto de investimento sentimental, descrita por Zelizer no contexto histórico europeu e norte-americano, difundiu-se a ponto de se poder falar em uma globalização dessa idéia. A difusão da concepção da criança como dotada de direitos e necessidades materiais e emocionais específicas é uma forma de globalização cultural. Isso não quer dizer que essas idéias tenham produzido os mesmos efeitos em toda parte, isto é, os impactos da expansão dessas idéias interagem com os diversos contextos locais.

Contudo, o que importa para os propósitos dessa análise é registrar o apelo emocional dessas histórias infantis que refletem o valor sentimental creditado à realização do projeto de constituir família com filhos. A criança é descrita como pequena, perfeita, querida, desejada, especial, gordinha e angelical. É uma criança ideal, sendo que tudo que precisa é de amor. Embora seja possível reconhecer o sexo dos bebês através das ilustrações ou do nome atribuído à criança ("Maria Estrelinha"), não se faz praticamente distinções de gênero no tratamento dado aos bebês ou na forma de ser referir a eles. Salienta-se o potencial que eles têm de proporcionar alegria, de despertar afeição, a necessidade de proteção, e isso, a criança, independente do sexo, seria capaz de suscitar. Tal posicionamento, a partir da perspectiva das representações acerca da infância, é perfeitamente coerente com a ideologia da criança sacralizada. Como se aproximam dos anjos, $e$ esses não têm sexo, a criança sacralizada também é assexuada, portanto, se o gênero não é de todo apagado, ele é pouco sublinhado. Todavia, sabe-se que as pessoas que pretendem adotar costumam manifestar preferência por crianças do sexo feminino, brancas e com poucos meses ou mesmo dias de vida. Cabe observar que nos quatro livros selecionados aleatoriamente, a noção de amor incondicional à criança suplantou as clivagens

\footnotetext{
${ }^{17}$ YngVeSson, B. Um Niño de Cualquier Color... Op. cit.
} 
Era uma vez...

baseadas no gênero, mas não aquelas fundadas na raça. As crianças são da mesma cor de quem as adota, ou seja, brancas. Ainda quando se utiliza a metáfora da Maria Estrelinha, filha de estrela, estrelinha é. O critério da semelhança física para a identificação e reconhecimento mútuo de pais e filhos, ou ainda, a necessidade de imitar a natureza, é uma fronteira mais difícil de ser rompida.

O investimento emocional dos pais e a valorização da criança como objeto de desejo dos adultos se expressam na referência ao choro de felicidade ao terem o bebê nos braços pela primeira vez:

Conta de novo como eu era picurrucha e perfeitinha. Conta de novo a primeira vez em que você me abraçou e me chamou de filhinha querida. Conta de novo que você chorou de tanta felicidade! (Conta de novo a História da noite em que eu nasci)

Você irá conhecer a história do bebê do coração. O bebê que foi "escolhido" para fazer parte de uma família. (...) Num certo dia, o casal teve uma grande idéia! "Vamos adotar um bebêt??" Um bebê especial... Um bebê escolhido, querido e desejado. "O nosso bebê do coração". (...) Como num quebra-cabeças, tudo se encaixou perfeitamente. Afinal... o bebê precisava de muito amor, e seus pais tinham muito amor para dar. Que sorte o bebê ter encontrado pais legais! Que sorte a dos pais por terem encontrado o bebê do coração! (Bebê do coração)

Naquela noite mesmo viram uma estrelinha vir chegando do alto do céu. Mamãe Estrela logo reconheceu! Era Maria Estrelinha que chegava para alegria de toda constelação! Era redondinha! De tão pequenininha e gordinha, quase não tinha pontinha. ( $A$ historinha bonitinha de Maria Estrelinha) 
Joice Melo Vieira

Você, quando percebia que estávamos com problemas, sempre nos ajudava.Você foi lá no céu, e continua sendo aqui na Terra, o nosso querido "Anjo da Guarda". (...) Quando você nasceu, lá estava eu, sua mamãe, com o papai, para recebê-lo. E que história linda começou então! Uma história de amor. Quando peguei você em meu colo, quando eu o abracei bem perto do meu coração, chorei de alegria! Papai também chorou de alegria. Pegou você, e embalou. Você estava conosco, para nos dar e receber todo o nosso amor. (Mamãe: por que não nasci de sua barriga?)

Um dado significativo desses livros infantis é que não foram empregados os termos adoção, adotado ou adotivo ao longo do texto. Somente em Bebê do coração utiliza-se o verbo adotar uma única vez: "(...) Num certo dia, o casal teve uma grande idéia! 'Vamos adotar um bebêl?' Um bebê especial..." Opta-se constantemente pelo uso de figuras de linguagem (metáfora, metonímia e eufemismos) para se remeter aos genitores, adotantes e adotados. $\mathrm{O}$ adjetivo adotivo é preterido, sendo substituído por designações como: "escolhido", "especial" ou "do coração". Essa forma de falar da adoção abre precedente para alguns questionamentos, afinal, esta omissão do termo dá margem para que se pense que a referência à condição de adotado é considerada tabu. A substituição dos termos "adotivo", "adotado" e "adoção" pode involuntariamente alimentar o preconceito, justamente porque parece haver um certo desconforto em utilizálos. A ênfase de que a criança adotada é um "anjo" ou é "especial" pode ser interpretada como uma atitude compensatória que visa combater implicitamente a idéia de inferioridade da filiação adotiva, ainda presente no imaginário social.

Bebê do coração traz também uma ilustração simbolicamente representativa. $\mathrm{O}$ bebê aparece dentro de um coração e na direção dele correm os espermatozóides em forma de coração (figura 7). 
Era uma vez...

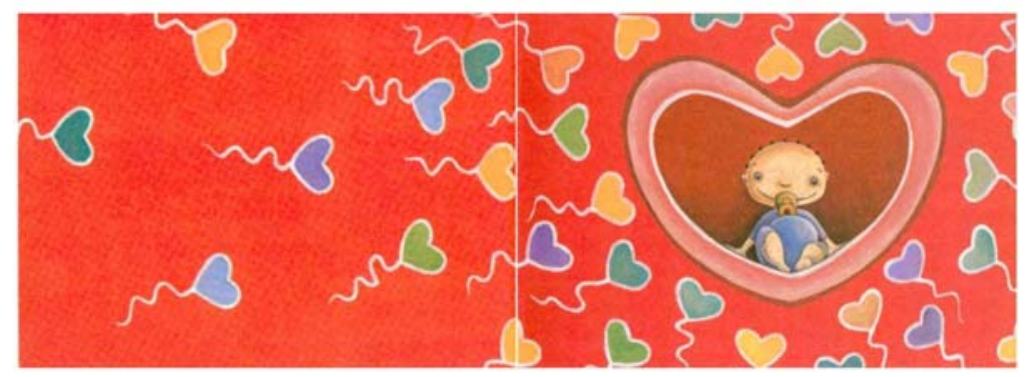

Figura 7 - Bebê do Coração, pp.14-15.

A imagem parece sobrepor a concepção da criança pelos pais biológicos e a afetividade dos pais adotivos dirigida à criança. Mesmo para falar do bebê do coração, a representação gráfica tomou como referencial o biológico. A ilustração pode tanto ser lida como o coração sendo o útero e os espermatozóides indo na sua direção, como, metaforicamente, o despertar do amor pela criança fosse comparável à fertilização. A ilustração parece dizer que assim como há quem tenha um filho no útero, há quem o tenha no coração.

Deve-se frisar que em nenhum dos quatro livros infantis a adoção é vinculada a qualquer tipo de conflito. O filho adotivo é muito amado e desejado pelos pais adotivos; os pais biológicos aparecem o mínimo possível, ou são simplesmente apagados da história, e todos, sem exceção, parentes, vizinhos e amigos aceitam muito bem a adoção. Todavia, como veremos no próximo tópico essa atmosfera plácida não reina absoluta em histórias infantis cujos autores não se identificam como pais adotivos.

\section{Clássicos infantis: confrontações e conflitos}

Os clássicos da literatura infantil compreendem inúmeras histórias de crianças que não são criadas por seus pais biológicos, a exemplo de $O$ patinho feio, Mogli, Cinderela, entre outros. Perdidas na floresta, abandonadas por seus pais ou órfãs, às 
vezes, elas encontram pais substitutos impiedosos e, invariavelmente, recebem a proteção de seres sobrenaturais e de animais. $\mathrm{Na}$ grande maioria dessas histórias, a paz só é restabelecida e a mais completa felicidade só é alcançada quando a personagem principal retorna à família ou ao grupo social de origem, ou estabelece relações amorosas que lhe oferecem a perspectiva de construir uma nova família.

A Psicanálise, tradicionalmente, explorou os mecanismos psíquicos, os motivos inconscientes e os símbolos escondidos nesses contos populares. ${ }^{18} \mathrm{O}$ conto de fadas, cheio de percalços em seu desenrolar, mas fadado ao final feliz, habilitaria a criança a assimilar a mensagem afirmativa de que por pior que pareça uma situação, tudo acaba bem. Confiando nisso, ela tornar-se-ia apta a enfrentar seus medos e desejos inconscientes. A mensagem afirmativa dos contos de fadas falaria às crianças:

(...) que uma luta contra dificuldades graves na vida é inevitável, é parte intrínseca da existência humana - mas que se a pessoa não se intimida, mas se defronta de modo firme com as opressões inesperadas e muitas vezes injustas, ela dominará todos os obstáculos e, ao fim, emergirá vitoriosa. ${ }^{19}$

Segundo Bettelheim, as histórias infantis modernas evitam abordar problemas existenciais, como a morte, o envelhecimento, o desejo de eternidade e as limitações da existência humana. São narrativas que se mantêm alheias aos dilemas existenciais. Esse afastamento dos problemas existenciais e a ausência deles nos livros infantis comprometeriam a formação das crianças, porque, para o psicanalista, elas necessitam que lhes sejam dadas sugestões para lidar com questões existenciais. Os contos foram, no passado, e têm o potencial de ser, no presente, uma maneira

${ }^{18}$ Bettelheim, Bruno. A psicanálise dos contos de fadas. Rio de Janeiro, Paz e Terra, 1980

${ }^{19}$ ID. IB., p.14. 
Era uma vez...

de preparar as crianças para enfrentar as dificuldades que virão a encontrar em suas vidas.

Pensando nos livros dos quais tratamos na seção anterior, não há em qualquer das histórias uma única personagem que seja contrária à adoção. A inserção de uma personagem desse tipo $e$ sua confrontação com as personagens principais poderiam contribuir para que a criança desenvolvesse estratégias que a ajudassem a lidar com os olhares curiosos de estranhos em lugares públicos, ou mesmo com o distanciamento mantido por algum parente que lhe confere tratamento distinto dado aos outros membros da família. Se a ausência de conflitos nesses livros faz parecer, ao menos às crianças muito pequenas, que a realidade social não reserva nenhum preconceito em relação aos filhos adotivos, a própria existência desses livros já é por si só um elemento empírico que, se não denota uma mudança de atitude significativa de toda a sociedade sobre a adoção, evidencia como deveria ser a adoção na visão dos pais adotivos. Ou ainda como eles a interpretam: um "quebra-cabeça", onde "tudo se encaixou perfeitamente. Afinal... o bebê precisava de muito amor, e seus pais tinham muito amor para dar" (Bebê do Coração). Uma possível explicação para a necessidade de se produzir essa literatura particular pode ser, justamente, porque o amor recíproco entre crianças e os substitutos de seus pais biológicos não costuma estar presente nos clássicos infantis.

Em $O$ patinho feio ${ }^{20}$, datado da primeira metade do século XIX, Hans Christian Andersen narra os sofrimentos do pequeno cisne chocado por uma pata, que, cansado de ser magoado pelas brincadeiras de mau gosto de seus irmãos, resolve fugir. Ele encontrou guarida na casa de uma velha que o tratou bem nos primeiros tempos, mas depois, novamente rejeitado, foge. Até que um dia, já crescido, encontra um bando de cisnes. Reconhecendose igual a eles, junta-se ao grupo e finalmente sente-se aceito.

${ }^{20}$ Andersen, Hans Christian (1805-1875). O Patinho Feio. São Paulo, Rideel, 2000, Coleção Conta pra mim. [Tradução: Maria Cimolino, Grazia Parodi.] 
Joice Melo Vieira

Mogli, o menino $l o b o^{21}$ - um dos personagens mais conhecidos de The Jungle Books (1894-1895) escrito pelo angloindiano Rudyard Kipling - embora adotado por uma loba e contando sempre com a amizade e proteção da pantera Baguera e do urso Baloo, está em permanente conflito com os lobos das gerações mais novas e com o tigre Shere Khan que sempre faz intrigas a seu respeito. O tempo passa, e com a aproximação da idade adulta, Mogli vai se sentindo cada vez mais sozinho $e$ resolve ir viver com os humanos. Quando passa a viver na Vila vizinha à selva, ele acaba reencontrando sua mãe humana. ${ }^{22}$

${ }^{21}$ Disney EnTERPRISES. Mogli - O menino lobo. São Paulo, Manole, 1997.

${ }^{22}$ A versão de Mogli para o cinema, feita pelos estúdios Disney, tem pouco a ver com o livro, e na verdade modifica o seu final. Mogli volta a viver com os humanos, mas ao invés de reencontrar sua mãe, acaba apaixonado por uma garota da Vila. A animação The Jungle Book (1967) teve um primeiro projeto que foi descartado no início da década de 60, porque Walt Disney o considerou muito colado ao texto original do livro de Kipling. Para Disney, para que o filme fosse um sucesso de bilheteria deveria perder a atmosfera sombria, misteriosa $e$ melancólica na qual Mogli estava mergulhado e sujeito a todo o tipo de sofrimento na selva indiana. Os críticos que conheciam a obra do escritor angloindiano consideraram o filme uma farsa. Segundo o primeiro projeto que nunca foi executado, o filme começaria mostrando um livro cuja capa traria Mogli e um lobo, tendo como trilha sonora "Brothers All" ("Todos irmãos"), inspirado no tema do livro "whether we swim or crawl, we are of one blood" ("quer nademos ou engatinhemos, nós somos do mesmo sangue") $e$, no final, ao reencontrar sua mãe humana, Mogli cantaria a canção "I knew I belong to her" ("Eu sei que eu pertenço a ela"). O projeto que veio a ser concretizado nas telas em 1967, não incorporou as duas canções acima citadas, inseriu comicidade à história e cortou algumas personagens. As produções de Walt Disney têm sido reprovadas por terem retirado os conflitos essenciais de praticamente todos os contos infantis adaptadas para o cinema. Argumenta-se que ao deturpar as obras originais, com o intuito de torná-las digeríveis por seu público, as animações perderam em densidade e significação. Para seguir além, consultar: ABRAMOVICH, Fanny. Literatura Infantil: gostosuras e bobices. São Paulo, Scipione, 1997; Dıgo, Américo. Literatura Infantil: História, Teoria, Interpretações. Portugal, Porto, 1994. Sobre o filme The Jungle Book dos estúdios Disney, consultar http://www.animagic.hpg.ig.com.br/jungleb.html. Sobre Kipling, ver BRAVOVILlaSANTE, Carmen. História da Literatura Infantil Universal. Lisboa, Vega, 1977. 
Era uma vez...

Considerando inicialmente Mogli e $O$ patinho feio, percebese que há elementos comuns, a saber: a rejeição de uma parcela de indivíduos que lhes são muito próximos (os patinhos irmãos ou os lobos jovens e o tigre) que podem representar a parentela do filho adotivo; e o retorno ao grupo de nascimento representado pelo bando de cisnes ou pela mãe biológica, propriamente.

Cabe lembrar que as duas histórias são do século XIX, o que pode merecer algum comentário. Para Darnton ${ }^{23}$, contos são também documentos históricos, o que nos obriga a indagar sobre suas origens e significados em diferentes contextos. Para ele, a onipresença de madrastas e órfãos nos contos populares do início da França moderna não dialoga simplesmente com o imaginário infantil, como querem os psicanalistas. De acordo com Bettelheim, a fantasia de que os pais não são "os verdadeiros pais" seria universal. A razão de ser dessa fantasia seria que ela permitiria à criança sentir raiva dos pais sem que esse sentimento viesse acompanhado de culpa:

(...) a divisão típica do conto de fadas entre a mãe boa (normalmente morta) e uma madrasta malvada é útil para a criança. Não é apenas uma forma de preservar a mãe interna totalmente boa, quando na verdade a mãe real não é inteiramente boa, mas permite à criança ter raiva da "madrasta" malvada sem comprometer a boa vontade da mãe verdadeira, que é encarada como uma pessoa diferente. Assim, o conto de fadas sugere a forma da criança lidar com sentimentos contraditórios que de outro modo a esmagariam neste estágio onde a habilidade de integrar emoções contraditórias apenas está começando. A fantasia da madrasta malvada não só conserva intacta a mãe boa, como também impede a pessoa de se sentir culpada a respeito dos pensamentos e desejos raivosos quanto a ela - uma culpa que interferiria na boa relação com a mãe. ${ }^{24}$

${ }^{23}$ DARnton, R. O Grande Massacre de Gatos... Op. cit.

${ }^{24}$ Bettelheim, B. A psicanálise dos contos... Op. cit., p.86. 
Darnton, que critica a leitura atemporal que os psicanalistas fazem dos contos populares, apoiando-se em contribuições da demografia, da antropologia e da história vê que a estrutura dessas narrativas e a recorrência dos mesmos temas não estão meramente em sintonia com o inconsciente humano a-histórico que funciona hoje exatamente como sempre funcionou, como parecem sugerir os psicanalistas. Os contos retratam, segundo os olhos da arte, um mundo que de fato existiu. Um mundo onde as madrastas e os órfãos proliferavam em conseqüência de mortes prematuras devido a guerras, pobreza, doenças e complicações do parto que ceifavam a vida de muitas mulheres.

Os filhos postiços podem não ter sido tratados como Cinderela, mas as relações entre os irmãos, provavelmente, eram difíceis. Um novo filho, muitas vezes, significava a diferença entre pobreza e indigência. Mesmo quando não sobrecarregava a despensa da família, podia trazer a penúria para a próxima geração, aumentando o número de pretendentes, quando a terra dos pais fosse dividida entre seus herdeiros. ${ }^{25}$

A orfandade, a subnutrição, as madrastas más e o abandono pelos pais são temas que se repetem em vários contos populares do século XVIII, porque essas eram questões com as quais os camponeses se defrontavam não apenas em seu folclore, mas também na vida cotidiana. O que Darton afirma sobre os contos do século XVIII, provavelmente, vale em parte para os contos do século XIX, justamente o período de transição em que tem início o processo de domesticação da família $e$ da maternidade, quando as crianças começam a ser sacralizadas e a adquirirem, idealmente, valor particular como objeto de investimento sentimental, mais do que como objeto de exploração econômica. ${ }^{26}$

${ }^{25}$ DARnTON, R. O Grande Massacre... Op. cit., p.45.

${ }^{26}$ ZELIZER, V. Repenser le marché... Op. cit. 
Era uma vez...

No final do século XIX surgem as novelas sentimentais que trazem como protagonistas crianças infelizes e abandonadas. ${ }^{27} \mathrm{Um}$ dos romances de maior sucesso dessa fase foi Sem Familia de Hector Malot (1888) que "fez forçosamente chorar muitas crianças francesas e européias, pois o livro foi imediatamente traduzido, obtendo uma larga divulgação". ${ }^{28}$ Comparando-se esse romance com Mogli ou $O$ patinho feio, cujos protagonistas cedo ou tarde conquistaram um ambiente familiar e a aceitação de seus pares, há um notável aumento do apelo sentimental e humanitário em Sem Família. O uso da narração em primeira pessoa faz calar ainda mais fundo o sofrimento do menino enjeitado, além de aguçar certa preocupação social ao denunciar uma sociedade tirânica com as crianças:

Sou um enjeitado!

Nunca me apercebi, até aos oito anos, de que aquela mãe com uma grandeza d'alma inimaginável! - fautora de tanta coisa bela e boa - sabe Deus com que sacrifícios! -, não era a minha mãe, a mãe verdadeira, uma mãe como os outros tinham, mas antes e muito simplesmente, a mulher que me criou. Céus! Que medonho e cruel foi sabê-lo. ${ }^{29}$

Medo, exploração e desamor caracterizavam a realidade da criança "sem família" e a novela sentimental enfatizará esses aspectos provocando piedade e comiseração nos leitores. Uma oposição interessante que emerge da aproximação entre o fragmento acima exposto $e$ as histórias infantis escritas por pais adotivos, é aquela existente entre "mulher que me criou" (Sem Familia) e "moça que me fez" (Conta de novo a história da noite em que eu nasci). Essas expressões utilizadas como subterfúgio para evitar reconhecer a maternidade de quem gera ou de quem

${ }^{27}$ Bravo-Villasante, C. História da Literatura... Op. cit.

${ }^{28}$ ID. IB., p.97.

${ }^{29}$ Diogo, A. Literatura Infantil... Op. cit. p.21 (ao citar trechos do trabalho de Malot). 
Joice Melo Vieira

cria, são, nitidamente, uma forma de manipular o parentesco, negando ou reafirmando quem é, dentre as mulheres entre as quais foram distribuídas as funções maternas, aquela que foi identificada como mãe.

Mas, afinal, reconhecer como mãe aquela que cria, como nos coloca as histórias infantis contemporâneas, ou aquela que gera, como parece apontar a literatura infantil clássica até o século $\mathrm{XIX}$, é uma questão que varia conforme o momento histórico ou de acordo com quem narra a história? Essa pode não ser uma questão tão simples de responder, no entanto, é possível que essas duas hipóteses estejam, na prática, entrelaçadas. Ou seja, a veemência com que as histórias infantis escritas por pais adotivos defendem a maternidade/paternidade de quem cria, porque são eles que deram e receberam o amor da criança, só adquire sentido no contexto histórico resultante da difusão de um certo ideal doméstico, segundo o qual o ambiente familiar deve ser "um lugar de afetividade onde se estabelecem relações sentimentais entre o casal e seus filhos, um lugar de atenção à infância (cor-de-rosa ou sombrio)". ${ }^{30} \mathrm{O}$ que parece dar sinais desde o final do século XIX e que é reforçado ao longo do século XX, é a vitória de uma espécie de ideologia do amor. Um amor espontâneo, altruísta e, ao menos aparentemente, gratuito entre pais e filhos. O reconhecimento da existência ou ausência desse amor é o fator que passa a ser defendido como elemento determinante para identificar mães $e$ pais.

${ }^{30}$ ARIÈs, Philipe. Para uma História da Vida Privada. In: Duby et alii. (ed.) História da Vida Privada. Lisboa, Círculo de Leitores, 1990, vol. 3, p.15. 